\title{
Antiulcerogenic activity of Indigofera truxillensis Kunth
}

\author{
Maira Cola-Miranda', Victor Barbastefano ${ }^{1}$, Clélia Akiko Hiruma-Lima², Tamara Regina Calvo ${ }^{3}$, Wagner Vilegas ${ }^{3}$, \\ Alba Regina Monteiro Souza Brito ${ }^{1,4}$.
}

Biota Neotropica v6 (n3) -http://www.biotaneotropica.org.br/v6n3/pt/abstract?article+bn01006032006

\author{
Date Received 12/12/2005 \\ Revised 08/05/2006 \\ Accepted 09/01/2006
}

${ }^{1}$ Departamento de Fisiologia e Biofísica, Instituto de Biologia, Universidade Estadual de Campinas (UNICAMP), Campinas, SP, Brazil.

${ }^{2}$ Departamento de Fisiologia, Instituto de Biociências, Universidade Estadual Paulista (UNESP), Botucatu, SP, Brazil. ${ }^{3}$ Departamento de Química Orgânica, Instituto de Química, Universidade Estadual Paulista (UNESP), Araraquara, SP, Brazil. ${ }^{4}$ Departamento de Fisiologia e Biofísica, Instituto de Biologia, Universidade Estadual de Campinas (UNICAMP), CP 6109, CEP13083-970, Campinas, SP, Brazil. Phone 55-19-3788-6192, Fax: 55-19-3788-6185. E-mail: abrito@unicamp.br

\begin{abstract}
Cola-Miranda, M; Barbastefano, V.; Hiruma-Lima, C.A.; Calvo, T.R.; Vilegas, W. and Brito, A.R.M.S. Antiulcerogenic activity of Indigofera truxillensis Kunth. Biota Neotrop. Sep/Dec 2006 vol. 6, no. 3 http://www.biotaneotropica.org.br/v6n3/ pt/abstract?article+bn01006032006 ISSN 1676-0611
\end{abstract}

The genus Indigofera (Fabaceae) is used in folk medicine to treat gastrointestinal pain. In this study, we investigated the antiulcerogenic properties of Indigofera truxillensis Kunth. Oral administration of MeOH extract did not produce any signals of acute toxicity. The antiulcerogenic activity was assessed in different models of acute gastric ulcers (100\% ethanol, piroxicam 30 mg. $\mathrm{kg}^{-1}$, hypothermic restraint stress and pylorus ligature) in mice and rats. The animals were treated with the drugs lanzoprazole (30 mg.kg-1) or cimetidine (100 mg. $\mathrm{kg}^{-1}$ ) as positive controls depending on the performed model. In another experiment with ethanol-induced ulcers in rats, N-ethylmaleimide (NEM), a sulfhydryl group blocker, was also used. The MeOH extract, at doses of 250, 500 and 1000 mg. $\mathrm{kg}^{-1}$, inhibited the gastric lesions in all experiments: a) by 62\%, $69 \%$ and 32\%, respectively, in piroxicam-induced lesions, b) by 43\%, 71\% and 98\%, in ethanol-induced lesions, c) by $69 \%$, 64 and 89\%, in hypothermic-restraint stress-induced lesions, d) by 73\%, 82\% and 84\%, in pylorus ligature lesions. Significant changes in the total gastric acid levels were also found after intraduodenal administration of the $\mathrm{MeOH}$ extract in the ligated pylorus model. Pre treatment with NEM reduced partially the antiulcerogenic activity of the MeOH extract in ethanolinduced gastric lesions. This result indicates an increase in the levels of non-protein sulfhydryl groups by $\mathrm{MeOH}$ extract in the gastric mucosa. These results indicate that the $\mathrm{MeOH}$ extract has antisecretory and citoprotective effects that may be related to the presence of flavonoids detected by phytochemical analysis.

Key words: antiulcerogenic activity; Fabaceae; Indigofera truxillensis Kunth; medicinal plant; phenolic compounds.

http://www.biotaneotropica.org.br 


\section{Resumo}

Cola-Miranda, M; Barbastefano, V.; Hiruma-Lima, C.A.; Calvo, T.R.; Vilegas, W. and Brito, A.R.M.S.Atividade altiulcerogênica de Indigofera truxillensis Kunth. Biota Neotrop. Sep/Dec 2006 vol. 6, no. 3 http://www.biotaneotropica.org.br/v6n3/pt/ abstract?article+bn01006032006 ISSN 1676-0603

O gênero Indigofera (Fabaceae) é utilizado na medicina tradicional para distúrbios gastrintestinais. Em nosso trabalho foi investigada a propriedade antiulcerogênica da Indigofera truxillensis Kunth. A administração oral do extrato metanólico $(\mathrm{MeOH})$ não produziu efeitos tóxicos. A atividade antiulcerogênica foi avaliada em diferentes modelos agudos de úlcera gástrica (etanol 100\%, piroxicam $30 \mathrm{mg} \cdot \mathrm{kg}^{-1}$, estresse por retenção e frio e ligadura do piloro) em camundongos e ratos. Os animais foram tratados com lansoprazol (30 mg.kg $\left.{ }^{-1}\right)$ ou cimetidina $\left(100 \mathrm{mg} \cdot \mathrm{kg}^{-1}\right)$, que foram utilizados como controle positivo dependendo do modelo testado. Em outro experimento com úlcera induzida por etanol em ratos, N-etilmaleimida (NEM), um bloqueador dos compostos sulfidríla, também foi utilizado. O extrato metanólico, nas doses de 250, 500 e 1000 mg. $\mathrm{kg}^{-1}$, inibiu significativamente as lesões gástricas em todos os experimentos: a) 62\%, 69\% e 32\%, respectivamente, nas lesões gástricas induzidas por piroxicam, b) 43\%, 71\% e 98\%, nas lesões gástricas induzidas por etanol, c) 69\%, 64\% e 89\%, nas lesões gástricas induzidas por estresse por contenção e frio, d) 73\%, 82\% e 84\%, nas lesões gástricas induzidas por ligadura de piloro. Alterações significativas foram observadas na concentração total de ácido gástrico após a administração via intraduodenal do extrato $\mathrm{MeOH}$ no modelo de ligadura do piloro. Pré-tratamento com NEM reduziu parcialmente a atividade antiulcerogênica do extrato $\mathrm{MeOH}$ na úlcera induzida por etanol, o que sugere um aumento nos níveis de compostos sulfidríla pelo extrato $\mathrm{MeOH}$ na mucosa gástrica. Os resultados indicam que o extrato $\mathrm{MeOH}$ possui um efeito antisecretor e citoprotetor, e que tais efeitos podem estar relacionados com a presença de flavonóides detectados por análise fitoquímica no extrato $\mathrm{MeOH}$.

Palavras-chave: atividade antiulcerogênica; Fabaceae; Indigofera truxillensis Kunth; plantas medicinais; compostos fenólicos. 


\section{Introduction}

Numerous plants and herbs are used to treat gastrointestinal disorders in traditional medicine. There has been renewed interest in identifying new antiulcer drugs from natural sources (Brito et al. 1997). Before introduction of potent antiulcerogenic agents, i.e. $\mathrm{H}_{2}$-receptor antagonists, proton pump inhibitors, etc. plant remedies were widely employed for the treatment of various symptoms of peptic ulcer (Gurbuz et al. 2002).

The genus Indigofera (Fabaceae) contains herbaceous and shrub species found in tropical and subtropical regions, mainly in Africa (Lewis 1987). Indigofera truxillensis Kunth, commonly known as "anileira”, was first recorded by Bentham (1859) in the state of São Paulo, Brazil. This species is typical of the "cerrado" or Brazilian savannah, and has been used to treat gastrointestinal disorders such as gastrointestinal pain (Roig 1988). This species is known to be a rich source of flavonoids, alkaloids, steroids, proteins and carbohydrates (Leite et al. 2004).

The aim of this study was to evaluate the antisecretory and cytoprotective activities of a crude methanolic extract (MEOH) of I. truxillensis in four models of gastric lesions in mice and rats. We also assessed the acute toxicity of the $\mathrm{MeOH}$ extract and its influence on the mucosal content of non-protein sulfhydryl groups.

\section{Material and Methods}

\section{Animals}

Male Swiss albino mice (25-35 g) and male Wistar rats (200-250 g) from the Central Animal House of the Universidade Estadual de Campinas (CEMIB/ UNICAMP) were used. The animals were housed in cages with raised floors of wire mesh to prevent coprophagy and were fed a certified Nuvilab CR-a ${ }^{\circ}$ (Nuvital) diet with free access to water under standard conditions (12 h dark-12 h light, 60\% humidity at $21 \pm$ $1^{\circ} \mathrm{C}$ ). The animals were fasted before all assays. The drugs and $\mathrm{MeOH}$ extract were administered orally (by gavage), subcutaneously or intraduodenally using $0.9 \%$ $(\mathrm{w} / \mathrm{v}) \mathrm{NaCl}(10 \mathrm{ml} / \mathrm{kg})$ as the vehicle. All of the experiments were approved by the Institutional Committee for Ethics in Animal Research (protocol 616-2, CEEA/IBUNICAMP).

\section{Plant material and extract}

The aerial parts of I. truxillensis were collected along the Domingos Sartori highway, at Rubião Junior, Botucatu, São Paulo, Brazil (2252'20’'S, 48²6'37’'W), in June 2003, and were authenticated by Dr. Jorge Tamashiro of the Institute of Biology at UNICAMP. A voucher specimen (UEC: 131.827) was deposited in the Herbarium of the State University of Campinas.

\subsection{Extract preparation}

The aerial parts (230 g) of I. truxillensis were air dried ( 7 days at $40^{\circ} \mathrm{C}$ ) and powdered. The powdered aerial parts were exhaustively extracted with methanol at room temperature (3 times, $72 \mathrm{~h}$ each), and the extract was concentrated in vacuum to yield $40 \mathrm{~g}$ of residue.

\subsection{Chromatographic analyses of the $\mathrm{MeOH}$ ex- tract}

The chemical constituents present in the $\mathrm{MeOH}$ extract were screened according to the method of Wagner et al. (1996). The chromatographic analysis was done by TLC (Fluka silica gel on glass plates, $20 \mathrm{~cm}$ x 20 cm x $0.25 \mathrm{~mm}$ ) developed with $n$-butanol/acetic acid/ water (BAW, 4:1:1, v/v/v). Approximately $10 \mathrm{~mL}$ of the $\mathrm{MeOH}$ extract was spotted onto the TLC plate. Alkaloids were detected by spraying the plates with Dragendorff's reagent and iodoplatinate. Anthraquinones were detected using $10 \%$ potassium hydroxide solution in methanol. Flavonoids were detected by their intense fluorescence in visible or UV light when developed with a natural product/polyethylene glycol (NP/ PEG) reagent. General phenolic compounds were detected after exposition of the plates to ammonia vapors and immediately observing the fluorescent spots under UV light. Saponins and triterpenes were detected with anisaldehyde-sulphuric acid reagent which produced a range of colors after heating for $5 \mathrm{~min}$ at $100^{\circ} \mathrm{C}$. Tannins were detected with $5 \%$ ferric chloride solution in methanol and with $1 \%$ gelatin solution and iodine vapours. Standard solutions of $(+)$-catechin, rutin, isoquercitrin, quercetin, kaempferol, yohimbine, galic acid, tannin acid, lupeol and friedelin were prepared in methanol. The degree of glycosylation was assessed by the $R_{f}$ of the spots detected in the $\mathrm{MeOH}$ extract compared to the available standards.

\section{Drugs}

The following drugs were used: cimetidine, lansoprazole, piroxicam and NEM (N-ethyl-maleimide) were obtained from Sigma Chemical Co. (St. Louis, MO, USA). All of the reagents were of high purity. The $\mathrm{MeOH}$ extract obtained from the aerial parts of I. truxillensis was dissolved in a $0.9 \%(\mathrm{w} / \mathrm{v}) \mathrm{NaCl}$ solution. All reagents, drugs and $\mathrm{MeOH}$ extract were prepared immediately before use.

\section{Acute Toxicity}

The acute toxicity of the MeOH extract was assessed in mice as described by Souza Brito (1994). A single high dose of the $\mathrm{MeOH}$ extract (5000 mg. $\mathrm{kg}^{-1}$ body weight, p.o.) was administered to a group of 10 animals after a $12 \mathrm{~h}$ fast. 


\section{Acute gastric mucosa lesions}

The gastroprotective activity of the $\mathrm{MeOH}$ extract was assessed at doses of 250, 500 and 1000 mg. $\mathrm{kg}^{-1}$ p.o. in four models of experimentally-induced gastric ulcers (see below). Cimetidine or lansoprazole was used as a reference drug, depending on the experiment. All of the animals had free access to water. After each experiment, the animals were sacrificed by cervical dislocation, the stomach removed, opened along the great curvature, and fixed between two glass plates. The inner surface of the stomach was examined with a dissecting microscope (Nikon SMZ800) and the number of gastric lesions was counted. The ulcer index was calculated according to the method of Szelenyi \& Thiemer (1978).

\section{Gastric mucosal lesions induced by absolute ethanol}

These experiments were done as described by Morimoto et al. (1991) Rats were fasted for $24 \mathrm{~h}$ and $\mathrm{MeOH}$ extract, lansoprazole (30 mg. $\mathrm{kg}^{-1}$ ) or vehicle (solution $0.9 \%$ $\mathrm{NaCl}$ ) was administered orally. One hour after treatment, the animals received an oral dose of one $\mathrm{ml}$ of absolute ethanol and were sacrificed one hour later, as described before.

\section{Gastric secretion in pylorus ligature induced lesions}

For this assay, the method of Shay et al. (1945) was used with some modifications. The mice were fasted for 36 $\mathrm{h}$, but had free access to water. Immediately after pylorus ligature, the $\mathrm{MeOH}$ extract, cimetidine (100 mg. $\mathrm{kg}^{-1}$ ), or vehicle solution $(0.9 \% \mathrm{NaCl})$ was administered intraduodenally. The mice were sacrificed four hours later, the abdomen was opened and the stomach removed. The volume of gastric juice (ml), the $\mathrm{pH}$ and the ulcer index were determined. The total acid content of the gastric secretion was determined by titration to $\mathrm{pH} 7.0$ with $0.01 \mathrm{~N} \mathrm{NaOH}$.

\section{Gastric lesions induced by nonsteroidal antiin- flammatory drugs (NSAIDs)}

These experiments were done using the method of Rainsford (1987), with some modifications (Puscas et al, 1997). Gastric ulcers were induced using piroxicam (30 mg. $\mathrm{kg}^{-1}$, s.c.), administered to mice after a $24 \mathrm{~h}$ fast. The $\mathrm{MeOH}$ extract, cimetidine $\left(100 \mathrm{mg} . \mathrm{kg}^{-1}\right)$ or vehicle $(0.9 \% \mathrm{NaCl})$ was administered orally, 30 min before the induction of gastric ulcers. The mice were sacrificed by cervical dislocation four hours after ulcer induction and the ulcer index was determined as described before.

\section{Gastric lesions induced by hypothermic-re- straint stress}

For this model, the method of Levine (1971) was used, with some modifications. After a $36 \mathrm{~h}$ fast, mice received an oral dose of $\mathrm{MeOH}$ extract, cimetidine (100 mg. $\mathrm{kg}^{-1}$ ) or vehicle solution $(0.9 \% \mathrm{NaCl})$. One hour after treatment, the mice were immobilized in a restraint cage at $4^{\circ} \mathrm{C}$ to induce ulcers. The mice were sacrificed four hours after hypothermic-restraint stress and the ulcer index was calculated as described before.

\section{Contribution of mucosal non-protein sulfhy- dryl groups to cytoprotection}

The cytoprotective effect of mucosal non-protein sulfhydryl groups was assessed by the method of Takeuchi et al. (1989). Mice were fasted for $24 \mathrm{~h}$ and then allocated to different treatments. The control group received a subcutaneous injection of vehicle solution $(0.9 \% \mathrm{NaCl})$, while the others received an injection of NEM (10 mg. kg ${ }^{-1}$ ) by the same route. Thirty minutes later, all groups received either vehicle or MeOH extract (500 mg.kg-1) orally. After one hour, all animals received an oral dose of $0.2 \mathrm{ml}$ of $0.3 \mathrm{M} \mathrm{HCl} / 60 \%$ ethanol solution. The mice were sacrificed one hour later and the ulcer index was determined as described before.

\section{Statistical analysis}

The results were expressed as the mean \pm SD. Statistical significance was determined by one-way analysis of variance (ANOVA) followed by Dunnett's post-hoc test, with the minimum level of significance set at $\mathrm{P}<0.05$.

\section{Results and discussion}

The present study was designed to assess the antiulcerogenic activity of a $\mathrm{MeOH}$ extract of I. truxillensis. The phytochemical screening indicated that the main constituents of the $\mathrm{MeOH}$ extract were flavonoid glycosides. Acute administration of the $\mathrm{MeOH}$ extract (up to 5000 mg.kg-1 p.o.) did not produce signs of toxicity, and no significant changes in daily body weight or organ weight occurred during the next 14 days of observation (data not shown). Thus, this result probably indicates that the plant extract has no toxic effect. Based on previous studies with plant extracts (Gonzales \& Di Stasi 2002 and Antonio et al. 2004), oral doses of $\mathrm{MeOH}$ extract (250, 500 and 1000 mg. $\mathrm{kg}^{-1}$ ) were initially administered in order to establish a general profile of the antiulcerogenic activity. The reason for use an apparently high dose of crude extract is that this is the posology traditionally employed, i.e., a glass of tea or infusion several times by day for at least a week. Dose of $1 \mathrm{~g} . \mathrm{kg}^{-1}$ of crude extract presuppose the presence of the active principle in concentration of $10 \%$ for substances like cimetidine (100 mg. $\mathrm{kg}^{-1}$ ), 2\% for those similar to omeprazol (20 mg. $\mathrm{kg}^{-1}$ ) and of $0.1 \%$ for those like misoprostol ( $\left.1 \mathrm{mg}^{\mathrm{k}} \mathrm{kg}^{-1}\right)$, taking into consideration the dosage employed in antiulcer therapeutics (Brito 1996). 
Szabo et al. (1985) demonstrated the onset of vascular injury in the glandular mucosa of the rat stomach within one minute after the intragastric administration of ethanol. The pathogenesis of the vascular lesions is not known but may be partly related to a direct effect of ethanol and its metabolites on endothelial cells.

After ingestion, ethanol diffuses into the mucosa and stimulates the formation of proinflammatory mediators by resident granulocytes and/or other mucosal cells (epithelial and endothelial cells) (Kvietys et al. 1990). Acute treatment with ethanol increases oxidative stress, DNA damage, xanthine oxidase activity and malondialdehyde levels and decreases the total glutathione content in gastric mucosal cells (Marotta et al. 1999).

As shown in Table 1, the $\mathrm{MeOH}$ extract significantly protected, in a dose-dependent way, the gastric mucosa from ethanol-induced ulcers at all doses (250, 500 and 1000 mg.kg-1, with 43\%, 71\% and 98\% protection, respectively). Lansoprazole, substance orally used as a positive control in this experiment, at a dose of $30 \mathrm{mg} \cdot \mathrm{kg}^{-1}$, provided $68 \%$ protection against the gastric lesions induced by ethanol. These results indicated a promising antiulcerogenic activity of the $\mathrm{MeOH}$ extract and suggested that an antisecretory or cytoprotective action may be involved (Morimoto et al. 1991).

NSAIDs can damage the gastrointestinal mucosa by local injury, when surface cells are damaged and allow acid diffusion into the submucosa, and by systemic injury, when systemic inhibition of prostaglandin synthesis occurs, thereby reducing gastric mucus production, bicarbonate secretion, and mucosal blood flow (Bjorkman 1996). NSAIDs also delay the healing of peptic ulcers, interfere with the action of growth factors, decrease epithelial cell proliferation at the ulcer margin, decrease angiogenesis in the ulcer bed, and slow the maturation of granulation tissue (Schmassmann 1998).

Table 2 summarizes the results obtained with piroxicaminduced gastric lesions. The $\mathrm{MeOH}$ extract protected the gastric mucosa at low (250 mg.kg-1, 62\% reduction in the ulcer index) and intermediate (500 mg.kg-1 , 69\% reduction) doses, suggesting a cytoprotective mechanism via an increase in mucous and/or prostaglandin synthesis. The highest dose of $\mathrm{MeOH}$ extract $\left(1000 \mathrm{mg} \cdot \mathrm{kg}^{-1}\right)$ did not protected against gastric lesions induced by piroxicam. This lack of effect is typical of extracts rich in flavonoids, since in high levels of flavonoids show pro-oxidant instead of antioxidant activity (Galvez et al. 1994, 2000, Sanchez de Medina et al. 1996).

Gastric mucus plays an important role in gastric defensive mechanisms by acting as a protective barrier, mainly because of its glycoprotein content. The water stored by these glycoproteins prevents hydrogen ions from reaching the cell surface (Motilva et al. 1996). Prostaglandins play an important role in modulating the integrity of the gastric mucosa in the presence of gastric acid secretion (Curtis et al. 1995). The systemic inhibition of prostaglandin synthesis reduces gastric mucus production, bicarbonate secretion, and mucosal blood flow (Wallace 1992).

Stress-induced mucosal damage is generally considered to be the result of an imbalance between aggressive and defensive mucosal factors (Miller 1987). The hypothermic restraint-stress model used here increases acid secretion and decreases the gastric mucosal pH (Murakami et al. 1985). Brozozowski et al. (2000) observed that the exposure of rats to $3.5 \mathrm{~h}$ of stress induced by cold and restraint produced gastric lesions, and that this effect was accompanied by a decrease in prostaglandin $\left(\mathrm{PGE}_{2}\right)$ generation and $\mathrm{a}$ marked fall in gastric blood flow.

As shown in Table 3, oral administration of the $\mathrm{MeOH}$ extract inhibited gastric lesions induced by hypothermic restraint-stress at the three doses tested: $250 \mathrm{mg} \cdot \mathrm{kg}^{-1}(69 \%$ inhibition), 500 mg. kg-1 (64\% inhibition), and 1000 mg. kg ${ }^{-1}$ (89\% inhibition). These results suggest that active compounds present in the $\mathrm{MeOH}$ extract may act as a regulators of gastric acid secretion. This antiulcerogenic action of the $\mathrm{MeOH}$ extract could also be related to the recovery of the gastric mucosal integrity mediated by an increase in mucus and bicarbonate production or by restoration of the vascular integrity to maintain the local blood flow under physiological conditions.

The inhibition of acid secretion is the one of most important factors for the healing of gastric ulcers. In the pylorus ligature model, the $\mathrm{MeOH}$ extract significantly reduced gastric acidity $\left[\mathrm{H}^{+}\right]$at a dose of $500 \mathrm{mg} \cdot \mathrm{kg}^{-1}$, as did cimetidine (both given intraduodenally), when compared to control group (Table 4). These results show that a possible antisecretory effect is involved in the antiulcerogenic activity of the $\mathrm{MeOH}$ extract. In addition, the ulcer index decreased after treatment with the $\mathrm{MeOH}$ extract (500 mg. $\mathrm{kg}^{-1}$ and $1000 \mathrm{mg} \cdot \mathrm{kg}^{-1}$ ), without any change in the volume of gastric secretions, as also found to cimetidine.

Szabo et al. (1981) demonstrated a significant decrease in the mucosal levels of non-protein sulfhydryl compounds in ethanol-induced gastric damage. These non-proteic compounds are important for maintaining the integrity of the gastric mucosa. Endogenous sulfhydryl compounds mediate the protective effects of prostaglandins against gastric mucosal injury (Miller 1983). Potentiation of the mucosal injury by NEM, an SH blocker, may be explained by the enhanced microvascular permeability in the gastric mucosa and inhibition of the gastric motility commonly associated with the prevention of mucosal injury (Takeuchi et al. 1989).

As shown in Table 5, the frequency of gastric mucosal lesions to $113 \%$ in mice pretreated with saline + NEM, whereas mice pretreated with the $\mathrm{MeOH}$ extract + NEM showed an increase of only $77 \%$, thus suggesting that sulfhydryl compound were partially, involved with the gastroprotective effects of this extract. 
Table 1. Effects of lansoprazole and $\mathrm{MeOH}$ extract of I. truxillensis on gastric mucosal lesions induced by absolute ethanol in rats.

\begin{tabular}{cccccc}
\hline \hline Treatment (p.o) & $\mathbf{N}$ & Dose $\left(\mathbf{m g . k g}^{-1}\right)$ & Ulcer index & $\begin{array}{c}\text { Number of rats with } \\
\text { lesions }\end{array}$ & Inhibition (\%) \\
\hline Control & 8 & $10 \mathrm{ml. \textrm {kg } ^ { - 1 }}$ & $70.0 \pm 28.0$ & $8 / 8$ & - \\
Lansoprazole & 8 & 30 & $22.0 \pm 11.0^{* *}$ & $7 / 8$ & 68 \\
& 5 & 250 & $40.0 \pm 27.0^{*}$ & $5 / 5$ & 43 \\
$\mathrm{MeOH}$ extract & 5 & 500 & $20.0 \pm 4.5^{* *}$ & $4 / 5$ & 71 \\
& 5 & 1000 & $1.4 \pm 0.9^{* *}$ & $2 / 5$ & 98 \\
\hline
\end{tabular}

The results are expressed as the mean \pm SD. ANOVA $\mathrm{F}_{(4,26)}=12.451(\mathrm{p}<0.01, \mathrm{p}<0.05) \overline{\text { for the ulcer index. }}$ Dunnett's test; $* \mathrm{p}<0.05$ and $* * \mathrm{p}<0.01$ compared to the control group.

Table 2. Effects of cimetidine and $\mathrm{MeOH}$ extract of I. truxillensis on gastric mucosal lesions induced by piroxicam (NSAID)-in mice.

\begin{tabular}{ccccccc}
\hline $\begin{array}{c}\text { Treatment } \\
\text { (p.o) }\end{array}$ & $\begin{array}{c}\text { Dose } \\
\left(\mathbf{m g . k g}^{-1}\right)\end{array}$ & $\mathbf{N}$ & $\begin{array}{c}\mathbf{p H} \\
\text { (unit) }\end{array}$ & Ulcer index & $\begin{array}{c}\text { Number of mice with } \\
\text { lesions }\end{array}$ & $\begin{array}{c}\text { Inhibition } \\
\text { (\%) }\end{array}$ \\
\hline Control & $10 \mathrm{ml}_{\mathrm{kg}} \mathrm{kg}^{-1}$ & 8 & $2.4 \pm 0.7$ & $10.2 \pm 3.7$ & $8 / 8$ & - \\
Cimetidine & 100 & 8 & $3.2 \pm 1.0$ & $3.9 \pm 1.9^{* *}$ & $7 / 8$ & 62 \\
& 250 & 8 & $3.6 \pm 0.5^{* *}$ & $3.9 \pm 1.9^{* *}$ & $8 / 8$ & 62 \\
$\mathrm{MeOH}$ extract & 500 & 8 & $2.6 \pm 0.7$ & $3.2 \pm 1.6^{* *}$ & $7 / 8$ & 69 \\
& 1000 & 8 & $2.0 \pm 0.9$ & $6.9 \pm 2.6^{*}$ & $6 / 8$ & 32 \\
\hline
\end{tabular}

The results are expressed as mean $\pm \mathrm{SD}$. ANOVA $\mathrm{F}_{(4,35)}=10.966(\mathrm{p}<0.01, \mathrm{p}<0.05)$ for the ulcer index and 4.275 $(\mathrm{p}<0.01)$ for the $\mathrm{pH}$. Dunnett's test: ${ }^{*} \mathrm{p}<0.05$ and $* * \mathrm{p}<0.01$ compared to the control group.

Table 3. Effects of cimetidine and $\mathrm{MeOH}$ extract of I. truxillensis on gastric mucosal lesions induced by stress in mice.

\begin{tabular}{cccccc}
\hline \hline Treatment & $\mathbf{N}$ & $\begin{array}{c}\text { Dose } \\
\left(\mathbf{m g . k g}^{-1}\right)\end{array}$ & Ulcer index & $\begin{array}{c}\text { Number of mice } \\
\text { with lesions }\end{array}$ & Inhibition (\%) \\
\hline Control & 8 & $10 \mathrm{ml.kg}^{-1}$ & $13.5 \pm 12.2$ & $8 / 8$ & - \\
Cimetidine & 8 & 100 & $5.5 \pm 4.5$ & $8 / 8$ & 59 \\
& 7 & 250 & $4.3 \pm 3.1^{*}$ & $6 / 7$ & 69 \\
MeOH extract & 8 & 500 & $4.7 \pm 3.6^{*}$ & $6 / 8$ & 64 \\
& 8 & 1000 & $1.5 \pm 1.1^{* *}$ & $5 / 8$ & 89 \\
\hline
\end{tabular}

The results are expressed as mean $\pm \mathrm{SD}$. ANOVA $\mathrm{F}_{(4,34)=} 4.071(\mathrm{p}<0.05, \mathrm{p}<0.01)$ for the ulcer index. Dunnett's test: ${ }^{*} \mathrm{p}<0.05$ and ${ }^{*} \mathrm{p}<0.01$ compared to the control group. 
Table 4. Effects of cimetidine and $\mathrm{MeOH}$ extract of I. truxillensis, administered intraduodenally, on gastric juice parameters in pylorus ligature-induced gastric mucosal lesions in mice.

\begin{tabular}{cccccccc}
\hline Treatments & $\mathbf{N}$ & Dose $\left(\mathbf{m g . k g} \mathbf{- n}^{-1}\right)$ & $\begin{array}{c}\mathbf{p H} \\
(\mathbf{u n i t})\end{array}$ & $\begin{array}{c}\text { Gastric Volume } \\
(\mathbf{m l})\end{array}$ & $\begin{array}{c}\mathbf{[ H +}+] \\
(\mathbf{m E q} / \mathbf{m l} / \mathbf{4 h})\end{array}$ & Ulcer Index & $\begin{array}{c}\text { Inhibition } \\
(\mathbf{\%})\end{array}$ \\
\hline Control & 13 & $10 \mathrm{ml} \cdot \mathrm{kg}^{-1}$ & $3.2 \pm 0.7$ & $1.2 \pm 0.7$ & $6.4 \pm 2.6$ & $4.6 \pm 1.3$ & - \\
Cimetidine & 5 & 100 & $5.6 \pm 1.1^{* *}$ & $1.3 \pm 0.6$ & $1.2 \pm 1.1^{* *}$ & $0 \pm 0^{* *}$ & 100 \\
& 5 & 250 & $3.6 \pm 0.5$ & $1.2 \pm 0.4$ & $3.3 \pm 1.9^{*}$ & $1.2 \pm 0.4^{* *}$ & 73 \\
MeOH extract & 5 & 500 & $4.2 \pm 1.1$ & $1.0 \pm 0.5$ & $1.6 \pm 0.8^{* *}$ & $0.8 \pm 0.4^{* *}$ & 82 \\
& 4 & 1000 & $3.7 \pm 1.5$ & $0.5 \pm 0.1$ & $3.5 \pm 0.9$ & $0.7 \pm 0.5^{* *}$ & 84 \\
\hline \hline
\end{tabular}

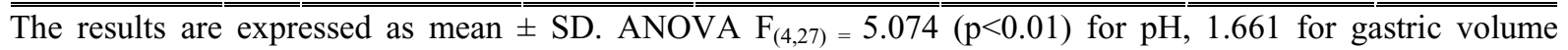
$(\mathrm{p}>0.05), 38.76$ for the ulcer index $(\mathrm{p}<0.01)$, and 9.289 for $\left[\mathrm{H}^{+}\right](\mathrm{p}<0.05, \mathrm{p}<0.01)$. Dunnett's test: ${ }^{*} \mathrm{p}<0.05$ and $* * \mathrm{p}<0.01$ compared to the control group.

Table 5. Effects of N-ethylmaleimide (NEM) and the $\mathrm{MeOH}$ extract of $I$. truxillensis (500 mg.kg ${ }^{-1}$ ) on $\mathrm{HCl} /$ ethanol-induced gastric mucosal lesions in mice.

\begin{tabular}{|c|c|c|c|c|}
\hline Treatments & $\mathbf{N}$ & Dose (mg.kg $\left.{ }^{-1}\right)$ & Ulcer index & Change (\%) \\
\hline Saline (s.c.) + Saline (p.o.) & 8 & $10 \mathrm{ml} \cdot \mathrm{kg}^{-1}$ & $27.6 \pm 10.5$ & - \\
\hline Saline (s.c.) $+\mathrm{MeOH}$ extract (p.o.) & 8 & 500 & $2.9 \pm 1.9^{* *}$ & - \\
\hline $\operatorname{NEM}($ s.c. $)+$ Saline (p.o.) & 8 & 10 & $59.0 \pm 20.0^{* *}$ & $+113 \%$ \\
\hline $\mathrm{NEM}($ s.c. $)+\mathrm{MeOH}$ extract (p.o.) & 8 & 500 & $49.0 \pm 19.0^{*}$ & $+77 \%$ \\
\hline
\end{tabular}

The results are expressed as mean \pm SD. ANOVA $\mathrm{F}_{(3.28)}=22.262(\mathrm{p}<0.01)$ for the ulcer index. Dunnett's test: ${ }^{*} \mathrm{p}<0.05$ and ${ }^{*} \mathrm{p}<0.01$ compared to the saline + saline group.

Phytochemical analysis revealed the presence of flavonoids in the $\mathrm{MeOH}$ extract. These compounds, which are important for the normal growth, development, and defense of plants (Cody et al, 19861986), also exert a gastroprotective action in mammals by increasing endogenous prostaglandin levels, decreasing histamine secretion, inhibiting Helicobacter pylori, and scavenging oxygen-derived free radicals (Park et al. 2004). This gastroprotection has been reported for various flavonoids including rutin, naringin, quercetin, kaempferol, sophoradin and luteolin (Lewis 1992, Di Carlo et al. 1999, Harborne \& Williams 2000, Borrelli \& Izzo 2000). Rutin reduces the levels of lipoperoxides and increases the activity of the anti oxidant enzyme GSH-Px (La Casa et al. 2000). Then the protective action of flavonoids may be assessed by the stimulation of mucus and bicarbonate secretion
(Cristoni et al. 1989, Gracioso et al. 2002) and by their inhibitory effect on the proton pump of parietal cells (Beil et al, 1995).

In conclusion, the results of this preliminary study indicated that the $\mathrm{MeOH}$ extract of the aerial parts of $I$. truxillensis has a gastroprotective action in several models of gastric lesions. This action is probably mediated by flavonoids. New series of experiment is in progress using a flavonoid rich fraction obtained from the $\mathrm{MeOH}$ extract of $I$. truxillensis as well as the isolation and identification of the flavonoids present in this fraction.

\section{Acknowledgments}

This work was supported by Brazilian institutions FAPESP (process $n^{\circ} 03 / 07017-4$ of the grant and $n^{\circ} 03 / 03110$ 0 for the scholarship) and CNPq. 


\section{References}

ANTONIO, J.M., GRACIOSO, J.S., TOMA, W., LOPEZ, L.C., OLIVEIRA, F. \& BRITO, A.R. 2004. Antiulcerogenic activity of ethanol extract of Solanum variabile (false “jurubeba”). J. Ethnopharmacol. 93: 83-88.

BEIL, W., BIRKHOLZ, C. \& SEWING, K.F. 1995. Effects of flavonoids on parietal cell acid secretion, gastric mucosal prostaglandin production and Helicobacter pylori growth. Arzneimittelforschung. 45: 697-700.

BENTHAM, G.M. 1859. Leguminosae I. In Flora Brasiliensis (K.F.P. VON MARTIUS, S.F.L. ENDLICHER, I. URBAN, A.W. EICHLER, and E. FENZL, eds.). Monachii; Friid Fleischer, 15.

BJORKMAN, D.J. 1996. Nonsteroidal anti-inflammatory drug-induced gastrointestinal injury. Am. J. Med. 101: 25S-32S.

BORRELLI, F. \& IZZO, A.A. 2000. The plant kingdom as a source of anti-ulcer remedies. Phytother. Res. 14: 581-591.

BRITO, A.R. 1996. How to study the pharmacology of medicinal plants in underdeveloped countries. J. Ethnopharmacol. 54: 131-138.

BRITO, A.R.M.S., COTA, R.H.S. \& NUNES, D.S. 1997. Gastric antiulcerogenic effects of Dalbergia monetaria L in rats. Phytother. Res. 11: 314-316.

BROZOZOWSKI, T., KONTUREK, P.C., KONTUREK, S.J., DROZDOWICZ, D., PAJDO, R., PAWLIK, M., BRZOZOWSKA, I. \& HAHN, E.G. 2000. Expression of cyclooxygenase (COX)-1 and COX-2 in adaptive cytoprotection induced by mild stress. J. Physiol Paris 94: 83-91.

CODY, V., MIDDLETON, E., \& HARBORNE, J. B. 1986. Plant Flavonoids in Biology and Medicine : Biochemical, Pharmacological and Structure-Activity Relationships. New York : Alan R. Liss.

CRISTONI,A., MALANDRINO, S. \& MAGISTRETTI, M.J. 1989. Effect of a natural flavonoid on gastric mucosal barrier. Arzneimittelforschung. 39: 590-592.

CURTIS, G.H., MACNAUGHTON, W.K., GALL, D.G. \& WALLACE, J.L. 1995. Intraluminal pH modulates gastric prostaglandin synthesis. Can. J. Physiol Pharmacol. 73: 130-134.

DI CARLO, G., MASCOLO, N., IZZO, A.A. \& CAPASSO, F. 1999. Flavonoids: old and new aspects of a class of natural therapeutic drugs. Life Sci. 65: 337-353.

GALVEZ, J., DE LA CRUZ, J.P., ZARZUELO, A., SANCHEZ DE, M.F., Jr., JIMENEZ, J. \& SANCHEZ DE LA, C.F. 1994. Oral administration of quercitrin modifies intestinal oxidative status in rats. Gen. Pharmacol. 25: 1237-1243.
GALVEZ, J., GARRIDO, M., MERLOS, M., TORRES, M.I. \& ZARZUELO, A. 2000. Intestinal anti-inflammatory activity of UR-12746, a novel 5-ASA conjugate, on acute and chronic experimental colitis in the rat. Br. J. Pharmacol. 130: 1949-1959.

GONZALEZ, F.G. \& DI STASI, L.C. 2002. Anti-ulcerogenic and analgesic activities of the leaves of Wilbrandia ebracteata in mice. Phytomedicine. 9: 125-134.

GRACIOSO, J.S., VILEGAS, W., HIRUMA-LIMA, C.A. \& SOUZA BRITO, A.R. 2002. Effects of tea from Turnera ulmifolia L. on mouse gastric mucosa support the Turneraceae as a new source of antiulcerogenic drugs. Biol. Pharm. Bull. 25: 487-491.

GURBUZ, I., USTUN, O., YESILADA, E., SEZIK, E. \& AKYUREK, N. 2002. In vivo gastroprotective effects of five Turkish folk remedies against ethanol-induced lesions. J. Ethnopharmacol. 83: 241-244.

HARBORNE, J.B. \& WILLIAMS, C.A. 2000. Advances in flavonoid research since 1992. Phytochemistry 55: 481-504.

KVIETYS, P.R., TWOHIG, B., DANZELL, J. \& SPECIAN, R.D. 1990. Ethanol-induced injury to the rat gastric mucosa. Role of neutrophils and xanthine oxidase-derived radicals. Gastroenterology 98: 909-920.

LA CASA, C.C., VILLEGAS, I., ARCON DE LA, L.C., MOTILVA, V. \& MARTIN CALERO, M.J. 2000. Evidence for protective and antioxidant properties of rutin, a natural flavone, against ethanol induced gastric lesions. J. Ethnopharmacol. 71: 45-53.

LEITE, S.P., DE MEDEIROS, P.L., DASILVA, E.C., DE SOUZA MAIA, M.B., DE MENEZES LIMA, V.L., \& SAUL, D.E. 2004. Embryotoxicity in vitro with extract of Indigofera suffruticosa leaves. Reprod. Toxicol. 18: 701-705.

LEVINE, R. J. 1971. A Method for Rapid Production of Stress Ulcers in Rats. In Peptic Ulcer (C.J. PFEIFFER, ed.). Munksgarrd, pp.92-97.

LEWIS, D.A. 1992. Antiulcer Drugs from Plants. Chemistry in Britain 28: 141-144.

LEWIS, G.P. 1987. Legumes of Bahia. Royal Botanic Gardens, Kew.

MAROTTA, F., TAJIRI, H., SAFRAN, P., FESCE, E. \& IDEO, G. 1999. Ethanol-related gastric mucosal damage: evidence of a free radical-mediated mechanism and beneficial effect of oral supplementation with bionormalizer, a novel natural antioxidant. Digestion 60: 538-543.

MILLER, T.A. 1983. Protective effects of prostaglandins against gastric mucosal damage: current knowledge and proposed mechanisms. Am. J. Physiol 245: G601-G623.

MILLER, T.A. 1987. Mechanisms of stress-related mucosal damage. Am. J. Med. 83: 8-14. 
MORIMOTO, Y., SHIMOHARA, K., OSHIMA, S. \& SUKAMOTO, T. 1991. Effects of the new anti-ulcer agent KB-5492 on experimental gastric mucosal lesions and gastric mucosal defensive factors, as compared to those of teprenone and cimetidine. Jpn. J. Pharmacol. 57: 495-505.

MOTILVA, V., LOPEZ, A., MARTIN, M.J., LA, C.C. \& ARCON DE LA, L.C. 1996. Cytoprotective activity of cisapride on experimental gastric mucosal lesions induced by ethanol. Role of endogenous prostaglandins. Prostaglandins 52: 63-74.

MURAKAMI, M., LAM, S.K., INADA, M. \& MIYAKE, T. 1985. Pathophysiology and pathogenesis of acute gastric mucosal lesions after hypothermic restraint stress in rats. Gastroenterology 88: 660-665.0

PARK, S., HAHM, K.B., OH, T.Y., JIN, J.H. \& CHOUE, R. 2004. Preventive effect of the flavonoid, wogonin, against ethanol-induced gastric mucosal damage in rats. Dig. Dis. Sci. 49: 384-394.

PUSCAS, I., PUSCAS, C., COLTAU, M., PASCA, R., TORRES, J., MARQUEZ, M., HERRERO, E., FILLAT, O. \& ORTIZ, J.A. 1997. Comparative study of the safety and efficacy of ebrotidine versus ranitidine and placebo in the prevention of piroxicam-induced gastroduodenal lesions. Arzneimittelforschung. 47: 568-572.

RAINSFORD, K.D. 1987. Gastric ulcerogenicity of non-steroidal anti-inflammatory drugs in mice with mucosa sensitized by cholinomimetic treatment. J. Pharm. Pharmacol. 39: 669-672.

ROIG, J.T. 1988. Plantas Medicinales, Aromaticas o Venenosas De Cuba. Editorial Cientifica-Tecnica, La Havana - Cuba. $164 \mathrm{pp}$.

SANCHEZ DE MEDINA, F., GALVEZ, J., ROMERO, J.A. \& ZARZUELO, A. 1996. Effect of quercitrin on acute and chronic experimental colitis in the rat. J. Pharmacol. Exp. Ther. 278: 771-779.

SCHMASSMANN, A. 1998. Mechanisms of ulcer healing and effects of nonsteroidal anti-inflammatory drugs. Am. J. Med. 104: 43S-51S.

SHAY, H., KOMAROV, S.A., FELS, S.S., MERANZE, D., GRUENSTEIN, M. \& SIPLET, H. 1945. A Simple Method for the Uniform Production of Gastric Ulceration in the Rat. Gastroenterology 5: 43-61.

SOUZA BRITO, A. R. 1994. Manual De Ensaios Toxicologicos “In Vivo”. UNICAMP, Campinas/SP - Brazil. $122 \mathrm{pp}$.

SZABO, S., TRIER, J.S. \& FRANKEL, P.W. 1981. Sulfhydryl Compounds May Mediate Gastric Cytoprotection. Science 214: 200-202.
SZABO, S., TRIER, J.S., BROWN, A. \& SCHNOOR, J. 1985. Early Vascular Injury and Increased Vascular-Permeability in Gastric-Mucosal Injury Caused by Ethanol in the Rat. Gastroenterology 88: 228-236.

SZELENYI, I. \& THIEMER, K. 1978. Distention Ulcer As A Model for Testing of Drugs for Ulcerogenic Side-Effects. Arch. Toxicol. 41: 99-105.

TAKEUCHI, K., OKADA, M., NIIDA, H. \& OKABE, S. 1989. Role of sulfhydryls in mucosal injury caused by ethanol: relation to microvascular permeability, gastric motility and cytoprotection. J. Pharmacol. Exp. Ther. 248: 836-841.

WAGNER, H. and BLADT, S. 1996. Plant Drug Analysis a Thin Layer Chromatography Atlas. Springer, Berlin.

WALLACE, J.L. 1992. Prostaglandins, NSAIDs, and cytoprotection. Gastroenterol. Clin. North Am. 21: 631-641.

Title: Antiulcerogenic activity of Indigofera truxillensis Kunth

Authors: Cola-Miranda, M; Barbastefano, V.; HirumaLima, C.A.; Calvo, T.R.; Vilegas, W. and Brito, A.R.M.S.

Biota Neotropica, Vol. 6 ( number 3): 2006

http://www.biotaneotropica.org.br/v6n3/pt/ abstract?article+bn01006032006

Date Received 12/12/2005 - Revised 08/05/2006

Accepted 09/01/2006

ISSN 1676-0611

http://www.biotaneotropica.org.br 